\title{
A phase I trial of recombinant gamma interferon in patients with cancer*
}

\author{
Kenneth A. Foon ${ }^{1}$, Stephen A. Sherwin ${ }^{2}$, Paul G. Abrams ${ }^{1}$, Henry C. Stevenson ${ }^{1}$, Pamela Holmes ${ }^{1}$, Annette E. Maluish ${ }^{3}$, \\ Robert K. Oldham ${ }^{1 * *}$, and Ronald B. Herberman ${ }^{1}$

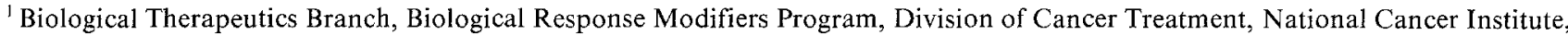 \\ NIH, Frederick Cancer Research Facility, Frederick, MD 21701, USA, \\ ${ }^{2}$ Genentech, Inc., South San Francisco, CA 94080, USA \\ ${ }^{3}$ Program Resources, Inc., NCI-Frederick Cancer Research Facility, Frederick, MD 21701, USA
}

\begin{abstract}
Summary. A total of 11 patients were treated on an escalating, single dose trial of recombinant gamma interferon (rIFN- $\gamma$ ), 6 patients by the i.m. and 5 patients by the i.v. route of administration. Dose ranges within each individual were from $0.05 \mathrm{mg} / \mathrm{m}^{2}$ of IFN $\left(1 \mathrm{mg} \geqslant 10 \times 10^{6}\right.$ units of IFN) escalating to $10 \mathrm{mg} / \mathrm{m}^{2}$. All dosages were delivered twice weekly and the i.v. dose was infused over $5 \mathrm{~min}$. The most common toxicities encountered included fever, chils, fatigue, anorexia, and granulocytopenia. The influenzalike symptoms were very similar to those encountered with IFN- $\alpha$ but were generally less severe. The granulocytopenia was dose-related and transient with recovery generally seen within $48-72 \mathrm{~h}$ following administration of $\mathrm{rIFN}-\gamma$. Absolute granulocyte counts only rarely dropped below $1000 \mathrm{~mm}^{3}$. Hepatotoxicity was not observed. IFN levels were determined by both a bioassay and an enzyme-linked immunosorbent assay. By the i.v. route, the peak level of IFN activity could usually be seen at completion of the infusion with a serum half-life of $30 \mathrm{~min}$. By the i.m. route, the peak level of serum activity was generally detected between $4-8 \mathrm{~h}$ with a serum half-life of $4.5 \mathrm{~h}$ after the initial elimination phase. Peak IFN levels appeared to correlate with maximum toxicity. One patient with melanoma had a $25 \%$ reduction in a cutaneous lesion, but there were no other minimal, partial, or complete responses.
\end{abstract}

\section{Introduction}

Interferons (IFNs) clearly have a wide variety of antiproliferative and immunomodulatory effects, which have led to extensive clinical trials of various IFN preparations in

\footnotetext{
* This project has been funded at least in part with Federal funds from the Department of Health and Human Services, under contract number NOI-CO-23910 with Program Resources, Inc. The contents of this publication do not necessarily reflect the views or policies of the Department of Health and Human Services, nor does mention of trade names, commercial products, or organizations imply endorsement by the U.S. Government. ** Present address: Biological Therapy Institute, Franklin, TN 37064, USA

Offprint requests to: $\mathrm{K}$. A. Foon, University of Michigan, School of Medicine, Division of Hematology and Oncology, Simpson Memorial Research Institute, 102 Observatory Road, Ann Arbor, MI 48109, USA
}

the treatment of patients with advanced cancer. Most of the trials have been phase I and phase II trials with IFN- $\alpha$. Trials with IFN- $\alpha$ have demonstrated substantial antitumor activity in favorable histology non-Hodgkin's lymphoma $[9,12,17,19,26]$, cutaneous T-cell lymphoma [3], hairy cell leukemia [23], kaposi's sarcoma $[11,16]$, and chronic myelogenous leukemia [30]. Activity has been reported for myeloma $[12,20]$, breast cancer $[15,27]$, renal cell carcinoma [22], and melanoma [4], but considerably less activity than that described for the hematopoietic malignancies described above. Recently, recombinant IFN- $\beta$ and natural and recombinant IFN- $\gamma($ rIFN- $\gamma)$ have been brought into clinical trials.

IFN- $\gamma$ has distinct antiproliferative and immunomodulatory properties from IFN- $\alpha$ and IFN- $\beta$, which might result in a different array of clinical effects. In early studies, IFN- $\gamma$ was shown to have more potent antiproliferative effects than the other IFN preparations [25]. However, many of these studies were performed with only partially purified IFN- $\gamma$ preparations that may have contained other biologically active molecules. Recent evidence suggests, however, that IFN- $\gamma$ has antiproliferative activity and in certain instances, the spectrum of activity differs from IFN- $\alpha$ and IFN- $\beta$ depending on the tumor cell type being tested. IFN- $\gamma$ has been shown to synergize with IFN- $\alpha$ and IFN- $\beta$ in in vitro antiproliferative assays using various human tumor cell lines $[5,8]$. IFN- $\gamma$ interacts with a different cell surface receptor than IFN- $\alpha$ and IFN- $\beta$ which explains the rationale for possible synergy between IFN- $\gamma$ and either IFN- $\alpha$ or IFN- $\beta$ [2]. IFN- $\gamma$ has also been shown to have potent macrophage activating effects, including induction of tumoricidal and microbicidal activity [15]. IFN$\gamma$ is thought to be the same molecule as macrophage activating factor by some investigators [29]. Augmentation of antibody-dependent cellular cytotoxicity [14], stimulation of peroxide generation [21], and enhancement of expression of Fc receptors, HLA-DR antigens, and class I histocompatibility antigens on the cell surface have been described [1]. IFN- $\alpha$ and IFN- $\beta$ are not as effective as IFN- $\gamma$ in enhancing class I and class II histocompatibility antigens $[6,7,18]$. These activities might be expected to make IFN- $\gamma$ a potent biological response modifier in cancer patients and thus warrant the clinical evaluation of IFN- $\gamma$ in the treatment of patients with cancer.

The gene for IFN- $\gamma$ has been successfully cloned and expressed in Escherichia coli [10]. The nucleotide and amino acid sequences of rIFN- $\gamma$ were determined to be ident- 
ical to native IFN- $\gamma$, except for the presence of a methionine residue at the N-terminal [24]. In this paper, we report the results of a phase I trial with a IIFN- $\gamma$ in patients with disseminated cancer. Patients received escalating single doses on a twice weekly schedule by i.m. or i.v. routes of administration and were monitored for evidence of clinical effects, levels of circulating IFN, and immunomodulatory effects. We report here the clinical and pharmacokinetic results.

\section{Materials and methods}

$r I F N-\gamma$ preparation. rIFN- $\gamma$ was prepared using recombinant DNA technology (Genentech, Inc., South San Francisco, Calif.). The final product was $>98 \%$ pure as determined by sodium dodecyl sulfate-polyacrylamide gel electrophoresis. Sterility, purity, pyrogenicity, and general safety met the standards of the Office of Biologics. Tests for endotoxin in the limulus assay routinely revealed $<0.5 \mathrm{ng} / \mathrm{mg}$ protein. Acute and subacute toxicology studies were carried out in two species (the rat and the squirrel monkey), and no significant toxicity was observed. The specific activity of rIFN- $\gamma$ was $\geqslant 1 \times 10^{7}$ units $/ \mathrm{mg}$ protein based on an antiviral bioassay with encephalomyocarditis virus and human A549 cells (standardized with NIH IFN$\gamma$ standard Gg 23-901-530).

Patient selection. A total of 11 patients with disseminated malignancy refractory to standard therapy were entered onto this trial (Table 1). All patients were required to have an ambulatory performance (Karnofsky) score of $60 \%$, no intervening anticancer therapy for a minimum of 4 weeks, and adequate hematologic (white blood cell count $>4000 / \mathrm{mm}^{3}$, platelet count $<100.000 \mathrm{~mm}^{3}$ ), hepatic (bilirubin $\leqslant 1.5 \mathrm{mg} / \mathrm{dl}$ ), and renal (creatinine $<2 \mathrm{mg} / \mathrm{dl}$ ) function. Informed consent was obtained from all patients prior to the initiation of therapy.

Study design. Patients received escalating single doses of rIFN- $\gamma$ by either i.m. or i.v. administration on a twice weekly schedule for seven or eight doses, respectively. One injection was given at each of the following dose levels: $0.05,0.1 ., 0.25,0.5,1,2.5,5$, and $10 \mathrm{mg} / \mathrm{m}^{2}\left(10 \mathrm{mg} / \mathrm{m}^{2}\right.$ was given i.v. only). All i.v. doses of rIFN- $\gamma$ were administered by infusion over a period of $5 \mathrm{~min}$. Dosage escalation continued in the absence of unacceptable systemic toxicity or tumor progression. The $10 \mathrm{mg} / \mathrm{m}^{2}$ dose was not given i.m.

Table 1. Patients entered on rIFN- $\gamma$ trial

\begin{tabular}{lcc}
\hline & Intramuscular & Intravenous \\
\hline Number & 6 & 5 \\
Age (median) & $45-64$ & $18-71$ \\
Sex (M/F) & $5 / 1$ & $2 / 3$ \\
Diagnosis: & & \\
$\quad$ Melanoma & 2 & 2 \\
$\quad$ Adenocarcinoma lung & 1 & \\
$\quad$ Multiple myeloma & 2 & 2 \\
$\quad$ Renal cell carcinoma & & 1 \\
$\quad$ Giant cell sarcoma & & \\
\hline
\end{tabular}

because an excessive injection volume of the available formulation would have been required.

The half-life for the i.v. route was calculated using nonlinear least square fit of a one compartment model, and for the i.m. route using a linear least square fit of the terminal portion of individual patient log concentration time curves.

Patient monitoring. Prior to the initiation of therapy, all patients underwent a history and physical examination, complete blood counts, serum chemistry profiles, chest $\mathrm{x}$ ray, electrocardiogram, and radiologic studies as appropriate for documentation of the extent of their disease. Following each injection of rIFN- $\gamma$, patients were carefully monitored for toxicity by repeated physical examinations, complete blood counts, and serum chemistry profiles. Reassessment of the extent of the disease to determine antitumor activity was performed as clinically indicated, during the course of the study or at its conclusion. All patients were monitored for levels of serum IFN, using an antiviral biological assay with encephalomyocarditis virus and human A549 lung carcinoma cells and by an enzyme-linked immunosorbent assay (ELISA) using a polyclonal antiserum to $\mathrm{rIFN}-\gamma$ with limits of detectability to $0.01 \mathrm{ng} / \mathrm{ml}$.

\section{Results}

\section{Clinical summary}

Of the patients who entered the study, 6 received i.m. and 5 received i.v. administrations. One patient with hairy cell leukemia was removed from the study after only one i.m. dose of rIFN- $\gamma$ as it was determined that his granulocyte count was too low to be followed adequately for potential IFN-related toxicity. Another patient treated with i.m. rIFN- $\gamma$ was removed after one dose due to abnormal liver function tests not related to the IFN therapy. Another patient with multiple myeloma was removed from the i.m. dose after three doses due to hypercalcemia. One patient with melanoma did not complete the i.v. therapy (three doses) due to abdominal pain that was subsequently determined to be secondary to an ovarian cyst.

The most notable toxicity was fatigue, which was clearly dose-related, with the degree of fatigue increasing with increasing doses of $\mathrm{IIFN}-\gamma$, and it was more prolonged by the i.m. route of administration. The degree of fatigue appeared to be dose-limiting at $5 \mathrm{mg} / \mathrm{m}^{2}$ by both routes of administrations with patients essentially bedridden for $12 \mathrm{~h}$ following this dose. Body temperature was $\geqslant 39^{\circ} \mathrm{C}$ in only one patient at the $5 \mathrm{mg} / \mathrm{m}^{2} \mathrm{i} . \mathrm{m}$. dose. Onset of fevers were demonstrated from $2-4 \mathrm{~h}$ (peak at $6-8 \mathrm{~h}$ ) following the i.m. dose and usually occurred within $1-2 \mathrm{~h}$ (peak at 4-6 h) following the i.v. dose. Hypotension with a systolic blood pressure $<90 \mathrm{~mm} \mathrm{Hg}$ was seen in only one patient treated with i.v. rIFN- $\gamma$ at $0.25 \mathrm{mg} / \mathrm{m}^{2}$ and another at $5 \mathrm{mg} / \mathrm{m}^{2}$. A depression of granulocytes was common, but only two patients experienced granulocytopenia with between 500 and 1000 granulocytes $/ \mathrm{mm}^{3}\left(1\right.$ at $0.25 / \mathrm{m}^{2}$ i.v. and another at $5 \mathrm{mg} / \mathrm{m}^{2}$ i.m.). There was no depression of any other blood components including lymphocytes, platelets, and eryhtrocytes. There were no changes in serum chemistry profiles (except for those mentioned above) or physical findings. 
Table 2. Toxicity of rIFN- $\gamma$

\begin{tabular}{|c|c|c|c|c|c|c|c|c|c|c|c|}
\hline \multirow{3}{*}{$\begin{array}{l}\text { Route } \\
\text { i. m. } \\
\left(\mathrm{mg} / \mathrm{m}^{2}\right)\end{array}$} & \multirow{3}{*}{$\begin{array}{l}\text { No. } \\
\text { patients }\end{array}$} & \multicolumn{3}{|c|}{ Temperature $\left({ }^{\circ} \mathrm{F}\right)$} & \multirow[t]{3}{*}{ Chills } & \multirow[t]{3}{*}{ Fatigue } & \multirow[t]{3}{*}{ Nausea } & \multirow[t]{3}{*}{ Vomiting } & \multirow{3}{*}{$\begin{array}{l}\text { Hypotension } \\
\text { (systolic < } \\
90 \mathrm{~mm} \mathrm{Hg} \text { ) }\end{array}$} & \multirow{2}{*}{\multicolumn{2}{|c|}{$\begin{array}{l}\text { Granulocytopenia } \\
\qquad\left(\mathrm{mm}^{3}\right)\end{array}$}} \\
\hline & & $99-100$ & $101-102.9$ & $\geqslant 103$ & & & & & & & \\
\hline & & & & & & & & & & $500-1000$ & $<500$ \\
\hline 0.05 & 6 & 3 & 2 & 0 & 3 & 1 & 0 & 0 & 0 & 0 & 0 \\
\hline 0.1 & 4 & 4 & 0 & 0 & 2 & 3 & 0 & 0 & 0 & 0 & 0 \\
\hline 0.25 & 4 & 3 & 1 & 0 & 0 & 3 & 0 & 0 & 0 & 0 & 0 \\
\hline 0.5 & 3 & 2 & 1 & 0 & 2 & 3 & 0 & 1 & 0 & 0 & 0 \\
\hline 1.0 & 3 & 1 & 2 & 0 & 2 & 3 & 0 & 1 & 0 & 0 & 0 \\
\hline 2.5 & 3 & 0 & 3 & 0 & 2 & 3 & 0 & 1 & 0 & 0 & 0 \\
\hline 5.0 & 3 & 0 & 2 & 1 & 3 & 3 & 1 & 1 & 0 & 1 & 0 \\
\hline
\end{tabular}

i. V.

\begin{tabular}{llllllllllll}
0.05 & 5 & 3 & 2 & 0 & 1 & 1 & 0 & 0 & 0 & 0 & 0 \\
0.1 & 5 & 2 & 3 & 0 & 3 & 2 & 0 & 0 & 0 & 0 \\
0.25 & 5 & 1 & 3 & 0 & 4 & 2 & 0 & 0 & 1 & 0 \\
0.5 & 4 & 1 & 3 & 0 & 4 & 2 & 1 & 0 & 0 & 0 \\
1.0 & 4 & 2 & 2 & 0 & 3 & 3 & 1 & 0 & 0 & 0 \\
2.5 & 4 & 2 & 2 & 0 & 4 & 3 & 1 & 1 & 0 & 0 \\
5.0 & 4 & 1 & 3 & 0 & 3 & 3 & 2 & 3 & 1 & 0 \\
10.0 & 4 & 1 & 3 & 0 & 4 & 3 & 3 & 1 & 0 & 0 \\
\hline
\end{tabular}
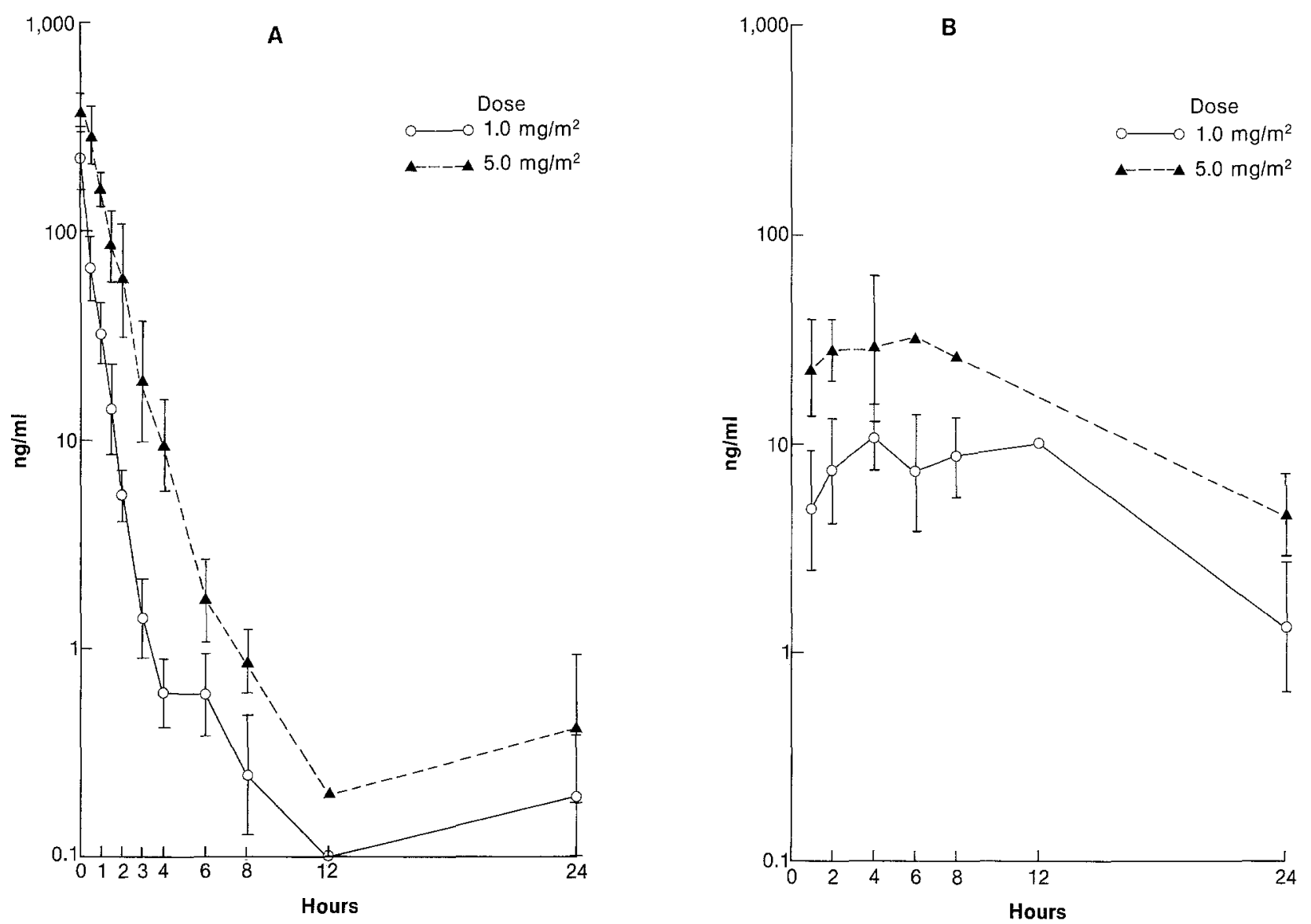

Fig. 1. Pharmacokinetics of serum rIFN- $\gamma$ after (A) i.v. or (B) i.m. administration of rIFN- $\gamma$ measured by an ELISA with standard deviations

\section{Antitumor activity}

No partial or complete responses were seen in any of the patients treated with $\mathrm{rIFN}-\gamma$ in this study. One patient with melanoma treated by the i.m. route had a minor regression of her only measurable disease which was a cutaneous lesion and was treated for 1 additional month with $0.25 \mathrm{mg}$ / $\mathrm{m}^{2}$ without further change. One patient with multiple myeloma demonstrated likely progressive disease growth following the third dose of rIFN- $\gamma$, as evidenced by increasing hypercalcemia, which required discontinuation of rIFN- $\gamma$ therapy. One patient with renal cell carcinoma 
completed the study but demonstrated minimal disease progression, and all of the other patients remained stable.

\section{Serum IFN levels}

Serum IFN activity was measured by both a biological antiviral assay and by an ELISA. Serum rIFN- $\gamma$ levels were routinely found by both the i.v. and i.m. routes of administration (Fig. 1). Detectable levels of IFN by the ELISA in $\mathrm{ng} / \mathrm{ml}$ were consistently found by both the i.m. and i.v. routes at the lowest dose of IFN $\left(0.05 \mathrm{mg} / \mathrm{m}^{2}\right)$ administered. The patterns of the curves of the bioassay generally paralleled the results of the ELISA although the bioassay did not detect activity by the i.m. route at doses below $1 \mathrm{mg} / \mathrm{m}^{2}$, whereas, detectable levels could be measured in the bioassay as well as ELISA at all doses by the i.v. route. These data clearly demonstrate a dose-dependent peak level of serum rIFN- $\gamma$ by both the i.m. and i.v. routes. The serum half-life was approximately $30 \mathrm{~min}$ by the iv.v. route and $4.5 \mathrm{~h}$ for the elimination phase following the i.m. injection. Antibodies ro rIFN- $\gamma$ (by both a neutralizing antibody detection assay and an immunoassay for antibody) were tested for in 8 of 11 patients on this trial, and none were detected.

\section{Discussion}

In this paper, we report the results of a rIFN- $\gamma$ study for patients with disseminated cancer. Our results indicate that rIFN- $\gamma$ can be given by both the i.m. and i.v.. routes with serum levels measured in an ELISA at all doses $\left(0.05-10 \mathrm{mg} / \mathrm{m}^{2}\right)$ and in a biological assay at all doses by the i.v. route and at $\geqslant 1 \mathrm{mg} / \mathrm{m}^{2}$ by the i.m. route. Previous studies with nonrecombinant IFN- $\gamma$ at comparable doses to those used in the current study reported no detectable serum levels following the i.m. route of administration [13, 28]. In both of these other studies measurements were carried out by a bioassay rather than an ELISA, with the latter having a sensitivity of $0.01 \mathrm{ng} / \mathrm{ml}$. Although we did detect serum IFN by the i.m. route using our bioassay, it was only at i.m. doses greater than those reported in these other studies. The serum half-life following the i.v. dose of rIFN$\gamma$ of $30 \mathrm{~min}$ was very similar to previous reports for i.v. bolus natural IFN- $\gamma[13,28]$. Toxicities were very similar to those reported for natural IFN- $\gamma$ as well as IFN- $\alpha$. The precise maximum tolerated dose for single dose administration could not be accurately assessed due to the potential cumulative toxicity of rIFN- $\gamma$ by the single dose escalation design of this study. Toxicities included fatigue, fever, chills, anorexia, occasional nausea and vomiting, headaches, mild hypotension, and granulocytopenia.

Pharmacokinetic data revealed a relatively rapid clearance for the i.v. administered $\operatorname{rIFN}-\boldsymbol{\gamma}$ and a more prolonged serum level by the i.m. route, with activities still demonstrable at all dose levels $24 \mathrm{~h}$ after the injection. As might be expected, the toxicities of the i.m. route were later in onset and more prolonged.

Immunologic studies will be reported separately. An optimum biological response modifying dose was not determined in this study. Future trials with rIFN- $\gamma$ should focus on determining an optimum biological response modifying dose. Possibly, the optimum biological response modifying dose is at a very low dose and we may have been unable to identify it because of our rapid dose escalation.

\section{References}

1. Basham T, Merigan T (1983) Recombinant interferon-gamma increases HLA-DR synthesis and expression. J Immunol 130: 1492

2. Branca AA, Baglione C (1981) Evidence that type I and II interferons have different receptors. Nature 294: 768

3. Bunn PA, Foon KA, Ihde DC, Winkler CF, Zeffren J, Sherwin SA, Oldham RK (1984) Recombinant leukocyte A interferon: an active agent in advanced cutaneous $T$ cell lymphoma. Ann Intern Med 109: 484

4. Creagan ET, Ahmann DL, Green JJ, Long HJ, Frytak S, O'Fallon JR, Itri LM (1984) Phase II study of low-dose recombinant leukocyte $\mathrm{A}$ interferon in disseminated malignant melanoma. J Clin Oncol 2: 1002

5. Czarniecki CW, Fennie CW, Powers DB, Estell DA (1984) Synergistic antiviral and antiproliferative activities of $E$. Coli derived human $\alpha, \beta, \gamma$ interferons. J Virol 49: 490

6. Fellous M, Kamoun M, Gresser I, Bono R (1979) Enhanced expression of HLA antigens and beta-2-microglobulin on interferon-treated human lymphoid cells. Eur J Immunol 9:446

7. Fellous M, Nir U, Wallach D, Merlin G, Rubenstein M, Revel M (1982) Interferon-dependent induction of mRNA for the major histocompatibility antigens in human fibroblasts and lymphoid cells. Proc Natl Acad Sci USA 79: 3082

8. Fleischmann WR, Jr., Fleischmann IM (1984) Potentiating effect of murine gamma interferon containing lymphokines on the antiviral and antiproliferative effects of murine alpha/beta interferon: Identification that the potentiation factor is gamma interferon itself. Antiviral Res 4: 221

9. Foon KA, Sherwin SA, Abrams PG, Longo DL, Fer MF, Stevenson $\mathrm{HC}$, Ochs JJ, Bottino GC, Schoenberger CS, Zeffren J, Jaffe ES, Oldham RK (1984) Recombinant leukocyte A interferon: an effective agent for the treatment of advanced non-Hodgkin's lymphoma. New Engl J Med 311: 1148

10. Gray PW, Goeddel DV (1982) Structure of the human immune interferon gene. Nature 298: 859

11. Groopman JE, Gottlieb MS, Goodman J et al. (1984) Recombinant alpha-2 interferon therapy for Kaposi's sarcoma associated with the acquired immunodeficiency syndrome. Ann Intern Med 100:671

12. Gutterman J, Blumenschein G, Alexanian R, Yap H-Y, Buzdar NU, Cabanillas F, Hortobagyi GN, Hersh EM, Rasmussen SL, Harman M, Kramer M, Pestka S (1980) Leukocyte interferon-induced tumor regression in human metastatic breast cancer, multiple myeloma, and malignant lymphoma. Ann Intern Med 93: 399

13. Gutterman JU, Rosenblum MG, Rios A, Fritsche HA, Quesada JR (1984) Pharmacokinetic study of partially pure $\gamma$-interferon in cancer patients. Cancer Res 44: 4164

14. Guyre PM, Morganelli PM, Miller R (1983) Recombinant immune interferon increases immunoglobulin $\mathrm{G} F \mathrm{~F}$ receptors on cultured human mononuclear phagocytes. J Clin Invest 72 : 393

15. Jerrells TR, Dean JH, Richardson G, Cannon GB, Herbermann RB (1979) Increased monocyte-mediated cytostasis of lymphoid cell lines in breast and lung cancer patients. Int $\mathrm{J}$ Cancer 23: 768

16. Krown SE, Real FX, Cunningham-Rundles $S$, Myskowski PL, Koziner B, Fein S, Mittleman A, Oettgen HF, Safai B (1983) Preliminary observations on the effect of recombinant leukocyte A interferon in homosexual man with Kaposi's Sarcoma. N Engl $\mathbf{J}$ Med 308: 1071

17. Louie AC, Gallagher JG, Sikora K, Levy R, Rosenberg SA, Merigan TC (1981) Follow-up observations on the effect of human leukocyte interferon on non-Hodgkin's lymphoma. Blood 58: 712

18. Lucero MA, Magdelenat H, Tridman WH, et al. (1981) Comparison of effects of leukocyte and fibroblast interferon on immunological parameters in cancer patients. Eur $\mathrm{J}$ Clin Oncol 18: 243 
19. Merigan TC, Sikora K, Breeden JH, Levy R, Rosenberg SA (1978) Preliminary observations on the effect of human leukocyte interferon on non-Hodgkin's lymphoma. N Engl J Med 299: 1449

20. Mellestedt H, Bjorkholm M, Johansson B, Ahe A, Holm G, Strander $\mathrm{H}$ (1979) Interferon therapy in myelomatosis. Lancet I: 245

21. Nathan CF, Murray HM, Wiebe M, Rubin BY (1983) Identification of interferon-gamma as the lymphokine which activated human macrophage oxidative metabolism and antimicrobial activity. J Exp Med 158:670

22. Quesada J, Swanson DA, Trindade A, Gutterman JU (1983) Renal cell carcinoma. Antitumor effects of leukocyte interferon. Cancer Res 43: 940

23. Quesada JR, Reuben J, Manning JT, Hersh EM, Gutterman $\mathrm{JU}$ (1984) Alpha interferon for induction of remission in hairy-cell leukemia. N Engl J Med 310 (1): 15

24. Rinderknecht E, O'Connor BH, Rodriguez H (1984) Natural human interferon-gamma: Complete amino acid sequence and determination of sites of glycosylation. J Biol Chem 259: 6790

25. Rubin BY, Gupta SL (1980) Differential efficacies of human type I and type II interferons as antiviral and antiproliferative agents. Proc Natl Acad Sci USA 77: 5928
26. Sherwin SA, Knost JA, Fein S, Abrams PG, Foon KA, Ochs JJ, Schoenberger C, Maluish AE, Oldham RK (1982) A multiple dose phase I trial of recombinant leukocyte A interferon in cancer patients. J Am Med Assoc 248: 2461

27. Sherwin SA, Mayer D, Ochs J, Abrams PG, Knost JA, Foon KA, Fein S, Oldham RK (1983) Recombinant leukocyte A interferon in advanced breast cancer. Ann Intern Med 98 (1) 598

28. Sherwin SA, Foon KA, Abrams PG, Heyman MR, Ochs JJ, Watson T, Maluish A, Oldham RK (1984) A preliminary phase I trial of partially purified interferon-gamma (IFN- $\gamma$ ) in patients with cancer. J Biol Response Mod 3: 599

29. Shultz RM, Kleinschmidt WJ (1983) Functional identity between murine $\gamma$ interferon and macrophage activating factor. Nature 305: 239

30. Talpaz M, McCredie K, Mavligit G, Gutterman JU (1983) Leukocyte interferon induced myeloid cytoreduction in chronic myelogenous leukemia. Blood 62: 689.

Received February 8, 1985/Accepted June 11, 1985 